\title{
IMPLIKASI YURIDIS TRANSFORMASI UNIT SYARIAH PERUSAHAAN ASURANSI/REASURANSI KE DALAM PERUSAHAAN ASURANSI/REASURANSI SYARIAH
}

\author{
Khotibul Umam \\ Fakultas Hukum, Universitas Gadjah Mada \\ email: khotibulumam@ugm.ac.id
}

disampaikan 25/10/2020 - di-review 02/11/2020 - diterima 20/11/2021

DOI: $10.25123 /$ vej.v7i2.4336

\begin{abstract}
In this article the author examines the juridical implications of transforming Units of Insurance/Reinsurance Company into Sharia Insurance/Reinsurance Company. It peruses two different models, the pure model, and the acquisition model. Both have its own strong and weak points. The pure models show its strongest point in being simpler about Sharia compliance. Its weakness, however, is the requirement of priory obtaining permit in principle and business permits. In contrast, the superiority of the acquisition model lies in its simplicity of licensing and conversion permits. Its disadvantage is in the complexity of contract conversion. Regarding assets and liabilities, strict adherence to the Sharia principles, voluntarisms, and avoidance of the mixing of halal and haram, is a pre-requisite
\end{abstract}

Keywords:

transformation; insurance-reinsurance; pure model; acquisition model

\begin{abstract}
Abstrak
Penelitian ini menelaah implikasi yuridis transformasi Unit Syariah Perusahaan Asuransi/Reasuransi ke dalam Perusahaan Asuransi/Reasuransi Syariah beranjak dari dua model pemisahan. Kedua model ini, pure model dan acquisition model memiliki kelebihan dan kekurangan masing. Akan ditelusuri dan digambarkan bagaimana dan seberapa jauh perbedaan implikasi yuridis dari implementasi kedua model itu. Ditemukan bahwa keunggulan pure model adalah kesederhaan terkait dengan ketaatan pada sharia. Sebaliknya kelemahannya adalah perlunya persetujuan prinsip dan izin usaha. Sedangkan acquisition model unggul dalam aspek kesederhanaan perizinan berupa izin konversi. Tetapi kelemahan muncul dalam kerumitan konversi akad. Terkait asset dan liabilitas perusahaan, maka perlu dipatuhi prinsip Syariah, kesukarelaan dan larangan pencampuran harta yang halal dengan yang haram.
\end{abstract}

Kata Kunci:

transformasi; asuransi; reasuransi; pure model; acquisition model

\section{Pendahuluan}

Undang-Undang Nomor 40 Tahun 2014 tentang Perasuransian (selanjutnya disebut UUP) memberikan pengaturan mengenai adanya kewajiban memisahkan Unit Syariah dari Perusahaan Asuransi/Reasuransi untuk kemudian bertransformasi ke dalam Perusahaan Asuransi/Reasuransi berdasarkan prinsip syariah. Syarat berlakunya kewajiban tersebut, yakni apabila kepemilikan dana tabarru' dan dana investasi dalam Unit Syariah yang bersangkutan atau setelah 
melewati waktu tententu, yakni 10 (sepuluh) tahun sejak berlakukanya undangundang a quo. ${ }^{1}$ Hal ini secara hukum menjadikan suatu unit dari Perusahaan Asuransi/Reasuransi konvensional akan bertransformasi menjadi badan hukum baru yang terpisah (new separate legal entity) dan secara ekonomi merupakan upaya pemaksaan melalui undang-undang agar perusahaan asuransi syariah mengoptimalkan kinerjanya, ${ }^{2}$ dengan lebih fokus pada pengembangan bisnis berbasis syariah, ${ }^{3}$ karena konsep pemisahan (spin-off) merepresentasikan upaya untuk menciptakan suatu tambahan produk derivatif dari suatu tiruan usaha sebelumnya yang mencerminkan independensi usaha syariah. ${ }^{4}$ Lebih lanjut sebagaimana diperbankan, urgensi dari dilakukannya pemisahan adalah untuk meningkatkan kepercayaan masyarakat terhadap asuransi syariah yang dikelola secara fokus dan independen. ${ }^{5}$

Pemisahan (spin-off) merupakan salah satu bentuk aksi korporasi yang baru diperkenalkan melalui Undang-Undang Nomor 40 Tahun 2007 tentang Perseroan Terbatas $^{6}$ dan secara spesifik diatur dalam UUP sebagai sarana transformasi Unit Syariah yang memiliki kesamaan pola dengan Perbankan dan Industri Keuangan Non-Bank (IKNB) lainnya. Khusus untuk industri perasuransian, UUP telah memiliki peraturan pelaksana, yakni berupa Peraturan Otoritas Jasa Keuangan (POJK) No. 67/POJK.05/2016 tentang Perizinan Usaha dan Kelembagaan Perusahaan Asuransi, Perusahaan Asuransi Syariah, Perusahaan Reasuransi, dan Perusahaan Reasuransi Syariah. Pada tahun 2020, POJK a quo mengalami perubahan dengan disahkan dan diundangkannya POJK No.

\footnotetext{
Undang-Undang R.I., No. 40 Tahun 2014, Perasuransian, L.N.R.I Tahun 2014 No. 337, Pasal 87.

2 Rachma Indraini, et. al, Efficiency Determinants of Islamic Insurance in Indonesia, Conference Paper dalam $2^{\text {nd }}$ ICIEBP Volume 2019, hlm. 176.

3 Lita Wulandari, et. al. Spin Off Feasibility Study of Sharia Financing Unit: Study in Adira Finance, 10, Jurnal Al-Iqtishad, Vol. 10, No. 2, July 2018, hlm. 300.

4 Lokot Zein Nasution, Strategi Spin-Off Bagi Pengembangan Keuangan Syariah: Tinjauan Pada Kasus Asuransi Syariah, Jurnal Dinamika Ekonomi Pembangunan (JDEP), Vol. 2, No. 2, 2019, hlm. 225.

5 Nursania Dasopang, Tinjauan Hukum Pemisahan (Spin-Off) Unit Usaha Syariah Menjadi Perusahaan Asuransi Syariah (Full Fledge), Jurnal Yurisprudentia, Vol. 5, No. 1, Juni 2019, hlm. 28.

6 Wardah Yuspin dan Kelik Wardiano, Islamic Banking Trajectories of Indonesia: Dealing with the Present and Shaping the Future, International Journal of Economic Research, Vol 14, No. 16 (Part 2), 2017, hlm. 34 .
} 
38/POJK.05/2020 tentang Perubahan atas Atas POJK No. 67/POJK.05/2016 tentang Perizinan Usaha dan Kelembagaan Perusahaan Asuransi, Perusahaan Asuransi Syariah, Perusahaan Reasuransi, dan Perusahaan Reasuransi Syariah. Ketentuan mengenai Pemisahan Unit Syariah tidak mengalami perubahan, sehingga masih mendasarkan pada POJK No. 67/POJK.05/2016.

Dalam rangka pemisahan Unit Syariah dimaksud dapat dilakukan dengan pendirian baru (pure model) atau dengan mengakuisisi perusahaan asuransi/perusahaan reasuransi lain yang kemudian dikonversi menjadi perusahaan asuransi/perusahaan reasuransi berdasarkan prinsip syariah, serta mengalihkan aktiva dan pasiva Unit Syariah kepada perusahaan tersebut (acquisition model). Hal ini tercermin dalam Pasal 18 ayat (1) POJK a quo, yakni bahwa Permisahan Unit Syariah dari Perusahaan Asuransi atau Perusahaan Reasuransi dapat dilakukan dengan cara:

a. Mendirikan Perusahaan Asuransi Syariah atau Perusahaan Reasuransi Syariah baru yang diikuti dengan pengalihan seluruh portofolio kepesertaan kepada Perusahaan Asuransi Syariah atau Perusahaan Reasuransi Syariah baru; atau

b. Mengalihkan seluruh portofolio kepesertaan pada Unit Syariah kepada Perusahaan Asuransi Syariah atau Perusahaan Reasuransi Syariah lain yang telah memperoleh izin usaha.

Pure model dan acquisition model akan dipilih oleh suatu perusahaan dalam melakukan transformasi melalui aktivitas pemisahan, tentu saja didasari oleh $d u e$ dilligence process terhadap aspek finansial dan aspek legal. ${ }^{7}$ Apabila dilihat dari skala ekonomi, Unit Syariah perusahaan asuransi secara umum dinilai masih terlalu kecil untuk melakukan pemisahan (spin-off), sehingga diperlukan antisipasi agar Unit Syariah tidak berguguran setelah menjadi perusahaan sendiri. ${ }^{8}$

7 Khotibul Umam, "Transformasi Kelembagaan Unit Usaha Syariah ke dalam Bank Umum Syariah di Indonesia”, Disertasi, Program Doktor Ilmu Hukum UGM, hlm. 370.

8 Kelvin Hianusa, "Standard an Alternatif Pemisahan Unit Usaha Syariah Disiapkan", artikel pada Harian Kompas, 27 September 2019, https://kompas.id/baca/utama/2019/09/27/standardan-alternatif-pemisahan-unit-usaha-syariah-disiapkan/, diakses 18 Maret 2020. 
Pada tahun 2019 baru terdapat 10 (sepuluh) dari 94 (sembilan puluh empat) Unit Syariah yang menyatakan siap melakukan pemisahan ${ }^{9}$, yang pada akhirnya hingga Desember 2019 terdapat empat Unit Syariah yang telah melepas diri dari induknya terdiri dari dua asuransi umum dan dua asuransi jiwa. Asuransi umum, yaitu Jasindo Syariah dan Askrida Syariah, sementara asuransi jiwa, yakni Asuransi Jaya Proteksi (AJP) Syariah dan ReINDO Syariah. ${ }^{10}$ Menurut Alexander Tubke terdapat tiga faktor yang mempengaruhi proses pemisahan, yakni faktor terkait aktivitas bisnis, faktor terkait organisasi dan manajemen perusahaan, serta faktor terkait hubungan dan dukungan. ${ }^{11} \mathrm{Hal}$ ini mengindikasikan adanya urgensi dan signifikansi pembahasan mengenai isu transformasi Unit Syariah Perusahaan Asuransi/Reasuransi ke dalam Perusahaan Asuransi/Reasuransi Syariah.

Urgensi atau arti penting Pemisahan Unit Syariah, mekanisme, keunggulan, dan kelemahan pure model dan acquisition model, serta treatment yang dilakukan oleh Perusahaan Asuransi/Reasuransi dalam rangka memastikan dipenuhinya prinsip syariah pada saat proses transformasi Unit Syariah menjadi fokus dalam penelitian ini. Tulisan ini berasal dari penelitian hukum normatif sehingga fokus pada data sekunder di bidang hukum, berupa bahan hukum primer dan bahan hukum sekunder terkait Hukum Asuransi dan Hukum Islam. Penelitian hukum normatif dilakukan pendekatan peraturan perundang-undangan dan pendekatan konsep. ${ }^{12}$ Analisis dilakukan secara kualitatif dan bersifat deskriptif analitis.

\section{Pembahasan}

Urgensi Pemisahan Unit Syariah, Mekanisme, Keunggulan dan Kelemahan Pure Model dan Acquisition Model

\footnotetext{
9 Republika, "OJK Sebut, 10 UUS Asuransi Berencana Spin Off" Artikel pada Harian Republika, Ahad 10 November 2019, https://republika.co.id/berita/q0qk3m370/ojk-sebut-10-uusasuransi-berencana-emspin-offem, diakses 18 Maret 2020.

10 CNN Indonesia, "OJK: Baru 4 Unit Syariah yang "Pisah" dari Induk Asuransi, Artikel pada CNN Indonesia, https://www.cnnindonesia.com/ekonomi/20190517160559-78-395823/ojk-baru4-unit-syariah-yang-pisah-dari-induk-asuransi, diakses 10 Mei 2020.

11 M. Nur Rianto Al Arif, The Effect of Spin-Off Policy on Financing Growth in Indonesian Islamic Banking Industry, Jurnal Al-Ulum Vol. 15, No. 1, June 2015, hlm. 175-176.

12 Peter Mahmud Marzuki, Penelitian Hukum: Edisi Revisi, Kencana, Jakarta, 2005, hlm. 133.
} 
Semua perbuatan hukum Unit Syariah merupakan tanggung jawab dan juga berisiko bagi entitas konvensional. Karena unit dimaksud merupakan satu bagian dari suatu badan hukum, sehingga tanggung jawab tidak lepas dari badan hukum itu sendiri, kecuali badan hukum yang bersangkutan menghilangkan, melepaskan melarutkan atau meniadakan bagian tersebut yang salah satunya melalui pemisahan (spin-off). ${ }^{13}$

Salah satu Perusahaan Asuransi yang telah melaksanakan Pemisahan Unit Syariah, yakni PT Askrida. Latar belakang dilakukannya Pemisahan tersebut, yakni guna memenuhi ketentuan regulator. Melalui spin off Unit Syariah, PT Askrida berharap pengembangan strategi dan bisnis akan lebih fokus, pertumbuhan full fledge akan lebih cepat, produktivitas meningkat dan diharapkan lebih efisien. ${ }^{14}$ Alasan yang hampir sama terdapat dalam Pemisahan Unit Syariah PT Asuransi Jasindo, yakni bahwa dengan menjadi perusahaan yang mandiri, PT Asuransi Jasindo Syariah berharap dapat tumbuh dan berkembang lebih pesat lagi, di samping dalam rangka melaksanakan perintah UUP. ${ }^{15}$ Sementara untuk Pemisahan Unit Syariah Perusahaan Reasuransi telah dilakukan oleh PT Reindo sehingga menghasilkan PT Reasuransi Syariah Indonesia (dikenal dengan ReINDO Syariah) sebagai Full Fledge Retakaful Pertama di Indonesia. ${ }^{16}$

Dalam kontek transformasi Unit Syariah PT Askrida, pasca Perseroan memperoleh ijin usaha dalam bidang Asuransi Umum dengan Prinsip Syariah dari Otoritas Jasa Keuangan melalui Keputusan Dewan Komisioner Otoritas Jasa Keuangan Nomor Kep 104/D.05/2017 tanggal 28 Desember 2017, PT Asuransi Askrida Syariah berkedudukan sebagai entitas anak dengan presentase

13 Nikmah Mentari dan Franciska Mifanyira Sutikno, Sustainable Development Goals (SDGs) Principle Towards Sharia Business Unit Pres-Spin Off 2023, Jurnal UNIFIKASI, Vol. 06, No. 02, 2019, hlm. 203.

14 Admin, Grand Launching Askrida Syariah, http://askridasyariah.co.id/berita/grand-launchingaskrida-syariah, diakses pada tanggal 5 Juni 2020.

15 Jasindo Syariah, https://lifepal.co.id/asuransi/jasindo-syariah/,diakses pada tanggal 14 Juni 2020.

16 Eduardo Simorangkir, "Resmi Merger, BUMN Reasuransi Ini Siap Go Internasional”, diakses dari https://finance.detik.com/bursa-dan-valas/d-3240765/resmi-merger-bumn-reasuransiini-siap-go-internasional, pada tanggal 15 Juni 2020. 
kepemilikan saham induk dalam entitas dimaksud per 2018 sebesar 99, 47\%. ${ }^{17}$ Harapan PT Askrida agar pengembangan strategi dan bisnis lebih fokus, pertumbuhan full fledge akan lebih cepat, produktivitas meningkat dan lebih efisien sebagaimana tersebut di atas, secara konkrit telah dilakukan langkahlangkah berupa: (1) penyesuaian struktur organisasi berdasarkan sistem kerja yang partisipatif serta selaras dengan best practices; (2) penguatan sumber daya insani, antara lain melalui berbagai pelatihan yang sesuai dengan posisi dan kebutuhannya; (3) pemanfaatan TI dan Digitalisasi; (4) implementasi tata kelola yang akuntabel dengan menerapkan prinsip-prinsip GCG di seluruh lapisan organisasi; serta (5) inovasi produk dan layanan, antara lain dengan meningkatkan nisbah bagi hasil investasi melalui instrumen deposito dan surat berharga Syariah. ${ }^{18}$

Apabila dicermati alasan dilakukannya Pemisahan Unit Syariah beberapa Perusahaan Asuransi/Reasuransi dimaksud, maka urgensi dilakukannya Pemisahan dalam perspektif yuridis adalah dalam rangka melaksanakan amanah UUP yang melalui Pasal 87 terdapat norma hukum yang bersifat memaksa dan diberikan batasan waktu paling lambat 10 (sepuluh) tahun sejak UUP diundangkan. Sebagaimana dalam Undang-Undang Nomor 21 Tahun 2008 tentang Perbankan Syariah (selanjutnya disebut UUPS), latar sosiologis diwajibkannya Pemisahan Unit Syariah menurut hemat Penulis adalah sebagai respon adanya kekurangpercayaan masyarakat terhadap tata kelola syariah yang dilakukan oleh lembaga konvensional, karena Unit Syariah ditinjau secara kelembagaan bukan badan hukum melainkan sebuah divisi yang melekat pada lembaga konvensional. Lembaga Pemisahan dalam Undang-Undang Nomor 40 Tahun 2007 tentang Perseroan Terbatas adalah salah satu bentuk aksi korporasi yang sepenuhnya digantungkan pada pertimbangan setiap Perseroan yang hendak melaksanakannya, sementar dalam UUPS dan UUP Pemisahan diwajibkan sebagai

\footnotetext{
17 Askrida, https://drive.google.com/file/d/1zKnhqPdM71bs-wybt6UjHrlwTpUSOagG/view, diakses 25 Desember, 2020, hlm. 148

18 Askrida Syariah, http://www.askrindosyariah.co.id/foto_berita/47Annual_Report_Askrindo_Syariah-2018.pdf, diakses 25 Desember, 2020, hlm. 6-7
} 
respon terhadap persepsi masyarakat sebagaimana dimaksud. Dengan demikian filosofi dan sekaligus urgensi Pemisahan Unit Syariah Perusahaan Asuransi/Reasuransi lebih berkaitan dengan keberadaan prinsip kepercayaan (fiduciary principle) yang harus dipenuhi oleh setiap lembaga keuangan, karena kepercayaan merupakan penentu kesuksesan dari lembaga tersebut.

Efisiensi merupakan suatu hal yang penting dalam perusahaan, termasuk di dalamnya perusahaan asuransi. ${ }^{19}$ Oleh karena itu penting untuk dipertimbangkan cara yang paling efisien dalam rangka melakukan pemisahan Unit Syariah ini oleh setiap perusahaan terkait. Mekanisme Pemisahan Unit Syariah, model pemisahan, keunggulan dan kelemahan dari setiap model Penulis identifikasi secara normatif pada bagian berikut.

Pertama, terkait mekanisme pemisahan Unit Syariah, UUP mengamanahkan untuk diatur melalui POJK. POJK dimaksud dalam hal ini adalah POJK No. 67/POJK.05/2016. Berdasarkan POJK a quo, Perusahaan yang akan melakukan pemisahan Unit Syariah dengan mendirikan Perusahaan asuransi syariah baru (pure model), harus memenuhi persyaratan pendirian Perusahaan baru. Mengingat Perusahaan Asuransi Syariah hasil pemisahan merupakan badan hukum yang terpisah dari badan hukum Perusahaan induk, hal-hal yang sebelumnya telah dipenuhi oleh unit syariah perusahaan induk wajib dipenuhi oleh Perusahaan Asuransi Syariah hasil pemisahan. ${ }^{20}$

Perusahaan Asuransi/Reasuransi wajib memberitahukan rencana Pemisahan Unit Syariah kepada pemegang polis melalui: (a) pengumuman rencana Pemisahan Unit Syariah dalam surat kabar; dan (b) surat kepada setiap

19 Sunarsih dan Fitriyani, Analisis Efisiensi Asuransi Syariah di Indonesia tahun 2014-2016 dengan Metode Data Envelopment Analysis (DEA), Jurnal Ekonomi \& Keuangan Islam, Vol. 4, No. 1, Januari 2018, hlm. 10.

20 Otoritas Jasa Keuangan, "FAQ POJK No. 67/POJK.05/2016 tentang Perizinan Usaha dan Kelembagaan Perusahaan Asuransi, Perusahaan Asuransi Syariah, Perusahaan Reasuransi, dan Perusahaan Reasuransi Syariah" https://www.ojk.go.id/id/kanal/iknb/regulasi/asuransi/peraturanojk/Documents/Pages/POJK-tentang-Perizinan-Usaha-dan-Kelembagaan-PerusahaanAsuransi,-Perusahaan-Asuransi-Syariah,-Perusahaan-Reasuransi/FAQ\%20POJK\%20672016.pdf, diakses 04 September 2020. 
pemegang polis. ${ }^{21}$ Pemisahan Unit Syariah harus memenuhi persyaratan sebagai berikut:

a. tidak mengurangi hak pemegang polis atau peserta;

b. dilakukan pada Perusahaan Asuransi atau Perusahaan Reasuransi yang memiliki bidang usaha yang sama; dan

c. tidak menyebabkan Perusahaan Asuransi Syariah atau Perusahaan Reasuransi Syariah yang menerima pengalihan Unit Syariah melanggar ketentuan yang berlaku di bidang perasuransian."22

Perusahaan Asuransi/Reasuransi wajib mengalihkan seluruh portofolio kepesertaan pada Unit Syariah kepada Perusahaan Asuransi/Reasuransi Syariah, yakni setelah Perusahaan Asuransi/Reasuransi Syariah hasil Pemisahan memperoleh izin usaha dari OJK, paling lambat 12 (dua belas) bulan sejak tanggal penetapan keputusan pemberian izin usaha dari 0JK. ${ }^{23}$ Perusahaan Asuransi/Reasuransi Syariah yang menerima pengalihan portofolio kepesertaan dari Unit Syariah wajib menyampaikan laporan penerimaan pengalihan portofolio tersebut kepada OJK paling lambat 10 (sepuluh) hari kerja setelah seluruh portofolio kepesertaan tersebut diterima. ${ }^{24}$

Kemudian Perusahaan Asuransi/Reasuransi yang memiliki Unit Syariah wajib mengajukan permohonan pencabutan izin pembentukan Unit Syariah kepada 0JK paling lambat 10 (sepuluh) hari kerja setelah portofolio kepesertaan pada Unit Syariah dialihkan kepada Perusahaan Asuransi/Reasuransi Syariah hasil Pemisahan.25 Pengajuan pencabutan diajukan oleh Direksi Perusahaan Asuransi/Perusahaan Reasuransi dengan dilampiri: (a) bukti penyelesaian hak dan kewajiban Unit Syariah; dan (b) surat pernyataan dari Direksi Perusahaan Asuransi atau Perusahaan Reasuransi bahwa langkah-langkah penyelesaian seluruh kewajiban Unit Syariah telah dilakukan sesuai dengan ketentuan dan

21 Peraturan Otoritas Jasa Keuangan, No. 67/POJK.05/2016, Perizinan Usaha dan Kelembagaan Perusahaan Asuransi, Perusahaan Asuransi Syariah, Perusahaan Reasuransi, dan Perusahaan Reasuransi Syariah, L.N.R.I Tahun 2016 No. 33, Pasal 18 ayat (3).

22 Id., Pasal 18 ayat (4).

23 Id., Pasal 21 ayat (2).

24 Id., Pasal 21 ayat (3).

25 Id., Pasal 22 ayat (1). 
apabila terdapat tuntutan di kemudian hari menjadi tanggung jawab Perusahaan Asuransi atau Perusahaan Reasuransi. ${ }^{26}$

Berbeda dengan mekanisme pure model yang diatur dalam POJK a quo secara detail, mekanisme acquisition model atau yang dalam POJK disebut dengan "mengalihkan kepada perusahaan yang telah memperoleh izin usaha" tidak diatur secara detail. Namun apabila dicermati, frase tersebut merujuk kepada kondisi perusahaan yang telah memperoleh izin usaha selaku Perusahaan Asuransi/Reasuransi Syariah sebagai perusahaan yang akan menerima portofolio kepesertaan dari Unit Syariah. Ada dua kemungkinan, yakni bahwa Perusahaan Asuransi/Reasuransi Syariah dimaksud, yakni perusahaan asuransi/reasuransi yang sejak semula didirikan sebagai Perusahaan Asuransi/Reasuransi Syariah atau merupakan Perusahaan Asuransi/Reasuransi Syariah hasil akuisisi dan konversi dari Perusahaan Asuransi/Reasuransi konvensional. Kemungkinan kedua ini disebut dengan acquisition model.

Kedua, isu berikutnya, yakni berkaitan dengan keunggulan dan kelemahan pure model dan acquisition model sebagai mekanisme pemisahan Unit Syariah. Model Murni (pure model), selain dapat dilakukan oleh satu Perusahaan Asuransi/Reasuransi yang memiliki Unit Syariah sebagaimana telah Penulis paparkan di atas, Pendirian Perusahaan Asuransi Syariah atau Perusahaan Reasuransi Syariah baru juga dapat dilakukan oleh lebih dari satu Perusahaan Asuransi atau Perusahaan Reasuransi yang memiliki Unit Syariah. ${ }^{27}$ Artinya Perusahaan Asuransi/Reasuransi Syariah adalah hasil pemisahan Unit Syariah dari beberapa Perusahaan Asuransi/Reasuransi.

Kesemuanya dilarang melakukan kegiatan usaha sebelum memperoleh izin usaha dari 0JK ${ }^{28}$ dan untuk memperoeh izin usaha, Direksi Perusahaan Asuransi atau Perusahaan Asuransi harus mengajukan permohonan izin usaha kepada OJK ${ }^{29}$ sesuai format yang ada ${ }^{30}$ dengan dilampiri dokumen berupa: (a) fotokopi

\footnotetext{
Id., Pasal 22 ayat (2).

Id., Pasal 20 ayat (1).

Id., Pasal 20 ayat (2).

Id., Pasal 20 ayat (3).

Id., Pasal 20 ayat (4).
} 
akta risalah RUPS yang menyetujui Permisahan; (b) fotokopi akta Pemisahan; (c) dokumen sebagaimana pengurusan pendirian perusahaan baru, serta dokumen tambahan berupa dokumen pemenuhan ketentuan Ekuitas Perusahaan dan bukti pendukung bahwa Tenaga Ahli yang dipekerjakan memiliki keahlian di bidang Asuransi Syariah dan/atau ekonomi syariah. ${ }^{31}$

Model Akuisisi (acquisition model) atau yang dalam regulasi disebut dengan pemisahan kepada perusahaan yang telah memperoleh izin usaha, khususnya Perusahaan Asuransi/Reasuransi Syariah hasil akuisisi dan konversi Perusahaan Asuransi/Reasuransi Konvensional memiliki perbedaan dengan Model Murni (pure model), karena dari proses pendirian berkaitan dengan perizinan hanya terdapat satu macam izin, yakni izin konversi yang sekaligus berfungsi sebagai izin usaha. Mekanisme konversi lebih ditekankan pada dipenuhinya persyaratan berupa: (a) tidak merugikan pemegang polis/tertanggung; (b) pemberitahuan kepada pemegang polis mengenai rencana konversi dan tata cara penyelesaian hak pemegang polis/tertanggung; dan (c) memindahkan portofolio pertanggungan kepada Perusahaan Asuransi lain, membayarkan bagian premi, dan/atau membayarkan nilai tunai pertanggungan, bagi tertanggung atau pemegang polis yang tidak bersedia menjadi pemegang polis atau peserta dari Perusahaan Asuransi Syariah. Di antara ketiga syarat tersebut, yang paling penting diperhatikan, yakni mengenai tata cara penyelesaian hak pemegang polis/tertanggung, manakala yang bersangkutan tetap bersedia menjadi peserta program asuransi dari Perusahaan Asuransi/Reasuransi Syariah, yakni berkaitan dengan konversi akad/perjanjian pertanggungan.

Dengan demikian Penulis berpendapat bahwa masing-masing cara yang diberikan oleh regulator memiliki keunggulan dan kelemahan masing-masing. Cara pertama, yakni secara pure model tidak mengalami kompleksitas berkaitan dengan isu sharia compliance, sedangkan cara kedua berupa acquisition model memiliki keunggulan dari aspek perizinan yang karena perusahaan yang bersangkutan sudah memiliki izin selaku Perusahaan Asuransi/Reasuransi

31 Id., Pasal 20 ayat (5). 
sehingga tinggal mengajukan izin usaha berupa izin konversi. Sebaliknya, cara pertama memiliki kelemahan, yakni memerlukan dua tahapan berupa persetujuan prinsip dan izin usaha, serta memerlukan permodalan Unit Syariah yang sudah kuat agar mampu bersaing dengan Perusahaan Asuransi/Reasuransi Syariah lain yang sudah eksis terlebih dahulu, sedangkan cara kedua memiliki kelemahan berupa kompleksitas konversi produk asuransi/reasuransi dari konvensional ke dalam produk asuransi/reasuransi syariah.

\section{Treatment Perusahaan Asuransi/ Reasuransi Guna Memastikan Dipenuhinya Prinsip Syariah}

Pada bagian sebelumnya sudah Penulis bahas mengenai urgensi, mekanisme, keunggulan, dan kelemahan masing-masing model pemisahan sebagai sarana transformasi Unit Syariah. Berikutnya Perlu Penulis paparkan mengenai status aset dan liabilitas Unit Syariah sebelum dan sesudah Pemisahan, serta perlakuan terhadap peserta program asuransi, pemegang saham, serta karyawan Unit Syariah dan Perusahaan Asuransi/Reasuransi yang menjadi target akuisisi dan konversi dalam rangka Pemisahan.

Prinsip Syariah yang dapat dijadikan sebagai rujukan dalam proses tersebut, yakni prinsip kesukarelaan (taradlin) sebagai penentu legalitas suatu transaksi ${ }^{32}$ dan prinsip percampuran harta antara yang halal dan yang haram. Berkaitan dengan kemungkinan adanya percampuran dana antara yang halal dan yang haram, secara umum terdapat dua pendapat ulama, yakni: Pertama, sebagian ulama berpendapat bahwa dana halal yang bercampur dengan dana nonhalal (haram) hukumnya adalah haram. Kedua, sebagian ulama berpendapat bahwa jika dana yang halal lebih dominan daripada dana nonhalal, maka keseluruhan dana tersebut menjadi halal. 33

Kedua prinsip tersebut berlaku, khususnya bagi Perusahaan Asuransi/Reasuransi yang melakukan pemisahan dengan acquisition model, yakni

32 Tim Laskar Pelangi, 2013, Metodologi Fiqih Muamalah: Diskursus Metodologis Konsep Interaksi Sosial-Ekonomi, Lirboyo Press, Kediri, hlm. $\mathrm{x}$.

33 Adiwarman A. Karim dan Oni Sahroni, 2015, Riba, Gharar, dan Kaidah-Kaidah Ekonomi Syariah: Analisis Fikih dan Ekonomi, PT. RajaGrafindo Persada, Jakarta, hlm. 217-218. 
pada saat memberikan tawaran alternatif bagi peserta/pemegang polis dari Perusahaan Asuransi/Reasuransi Syariah hasil akuisisi dan konversi untuk tetap bergabung dengan perusahaan yang bersangkutan atau diselesaikan hak dan kewajibannya. Sementara dalam pure model tidak dijumpai isu syariah seperti ini dikarenakan pure model lebih pada peningkatan status Unit Syariah menjadi Perusahaan Asuransi/Reasuransi Syariah dan model ini tidak berkaitan dengan perusahaan lain yang awalnya adalah konvensional.

Terlebih dahulu perlu Penulis sampaikan bahwa Pemisahan (spin-off) Unit Syariah memiliki kelebihan bagi pengembangan asuransi syariah, yakni: (a) kebermanfaatan dalam restrukturisasi perusahaan melalui pemecahan unit syariah; (b) diharapkan mampu meningkatkan profitabilitas yang lebih baik; (c) meningkatkan fokus perusahaan, baik perusahaan induk maupun anak perusahaan hasil pemisahan; (d) menjadi strategi diversifikasi usaha, dimana bagian-bagian yang tidak relevan dengan perusahaan induk sebaiknya dipisahkan; dan (e) bentuk implementasi manajemen strategi yang harus diiringi dengan penguatan manajemen dalam rangka meminimalisir beban biaya yang ditanggung dari konsekuensi pelaksanaan spin-off. ${ }^{34}$

Dari kelebihan-kelebihan dimaksud, point (c) dan (d) memiliki relevansi dengan tulisan ini, yakni bahwa dalam hal terjadi Pemisahan akan melahirkan konstruksi perusahaan kelompok, yang mana Perusahaan Asuransi/Reasuransi Syariah menjadi anak perusahaan yang fokus dalam memberikan jasa asuransi/reasuransi berbasis pada prinsip syariah dan sekaligus menjadi strategi diversifikasi dengan memisahkan aktivitas syariah ke dalam badan hukum yang mandiri. Dengan menjadi anak perusahaan yang merupakan badan hukum mandiri, maka menjadi penting dalam perspektif hukum untuk diketahui implikasi terhadap status aset Unit Syariah dan perlakuan terhadap pihak-pihak yang terkait.

34 Lokot Zein Nasution, "Strategi Spin-Off Bagi Pengembangan Keuangan Syariah: Tinjauan Pada Kasus Asuransi Syariah", Artikel pada Jurnal Dinamika Ekonomi Pembangunan (JDEP) Vol. 2 No. 2 (2019), hlm. 225. 
Pertama, berkaitan dengan implikasi terhadap status aset Unit Syariah sebelum dan sesudah Pemisahan Penulis tekankan pada portofolio kepesertaan pada Unit Syariah, serta portofolio kepesertaan pada Perusahaan Asuransi/Reasuransi Konvensional yang menjadi target akuisisi dan konversi. Apabila yang dipilih oleh pelaku pemisahan Unit Syariah adalah dalam bentuk pure model, maka secara hukum sebelum Pemisahan portofolio kepesertaan yang dikelola oleh Unit Syariah merupakan aset yang dimiliki oleh Perusahaan Asuransi/Reasuransi dimana suatu Unit Syariah bernaung dan setelah Pemisahan dengan membentuk Perusahaan Asuransi/Reasuransi Syariah yang notabene adalah badan hukum mandiri, maka portofolio kepesertaan tersebut beralih menjadi aset yang dimiliki oleh Perusahaan Asuransi/Reasuransi Syariah hasil Pemisahan. Dalam perspektif hukum Islam apabila yang terjadi adalah pure model, maka dengan asumsi bahwa Unit Syariah dikelola secara terpisah dari aktivitas konvensional dapat Penulis tegaskan bahwa sebelum dan sesudah pemisahan tidak mengubah status aset ditinjau dari kehalalan harta kekayaan dari Perusahaan Asuransi/Reasuransi Syariah hasil Pemisahan. Artinya portolio kepesertaan yang menjadi milik badan hukum baru tersebut tetap dikelola sesuai dengan prinsip syariah.

Agak kompleks ketika Pemisahan dilakukan secara acquisition model. Dengan asumsi bahwa pengelolaan Unit Syariah sudah sesuai dengan Prinsip Syariah, maka pemisahannya ke dalam Perusahaan Asuransi/Reasuransi Syariah yang sudah ada yang merupakan hasil akuisisi konversi Perusahaan Asuransi/Reasuransi Konvensional berpotensi memunculkan isu berkaitan dengan Hukum Islam, yakni percampuran antara aktiva dan pasiva Unit Syariah dan Perusahaan Asuransi/Reasuransi Syariah hasil konversi, sehingga berkaitan dengan perlakuan terhadap aset dan liabilitas Perusahaan Asuransi/Reasuransi menjadi hal yang perlu diperhatikan guna memastikan dipenuhinya Prinsip Syariah. Pada prinsipnya setelah dilakukan Pemisahan, sebagaimana dalam pure model, portofolio kepesertaan pada Unit Syariah beralih menjadi aset yang dimiliki oleh Perusahaan Asuransi/Reasuransi Syariah hasil Pemisahan dan terhadap status kesyariahan dari aset dan liabilitas Perusahaan Asuransi/Reasuransi 
Konvensional target akuisisi dan konversi perlu diperlakukan sedemikian rupa sehingga pada saat Pemisahan Unit Syariah, terhadap aset dan liabilitas tersebut betul-betul telah dilakukan purifikasi. Purifikasi dilakukan untuk meminimalisir keberadaan aset non-halal, sehingga ketika terjadi percampuran maka secara kuantitas aset halal jauh lebih besar daripada non-halal. Dengan demikian, mendasarkan pada pendapat kedua sebagaimana tersebut di atas, jika dana yang halal lebih dominan daripada dana nonhalal, maka keseluruhan dana tersebut menjadi halal.

Dengan demikian dapat Penulis tegaskan bahwa status aset Unit Syariah sebelum Pemisahan adalah menjadi milik Perusahaan Asuransi/Reasuransi Konvensional, sedangkan setelah Pemisahan sebagai konsekuensi munculnya badan hukum baru, maka aset dimaksud menjadi milik Perusahaan Asuransi/Reasuransi Syariah hasil pemisahan. Hubungan antara Perusahaan Asuransi/Reasuransi yang melakukan Pemisahan dan Perusahaan Asuransi/Reasuransi Syariah hasil pemisahan adalah hubungan induk dan anak perusahaan, sehingga tanggung jawab induk adalah sebesar saham yang dimiliki dengan tidak menutup kemungkinan ikut "intervensi" dalam tata kelola Perusahaan Asuransi/Reasuransi Syariah dengan meningat di antara mereka masih dalam satu kesatuan ekonomi. ${ }^{35}$

Kedua, terkait dengan perlakuan terhadap peserta program asuransi, pemegang saham, dan karyawan Unit Syariah, yakni diawali dengan adanya kewajiban Perusahaan Asuransi/Reasuransi untuk memberitahukan Pemisahan Unit Syariah kepada pemegang polis setelah permohonan izin usaha disetujui, yaitu melalui pengumuman Pemisahan Unit Syariah dalam surat kabar paling lambat 20 (dua puluh) hari kerja setelah memperoleh izin usaha dari 0JK dan surat kepada setiap pemegang polis. ${ }^{36}$ Kewajiban mengumumkan kepada pemegang polis juga berlaku pada saat akan dilakukan akuisisi dan konversi terhadap Perusahaan target guna memastikan bahwa akuisisi dan konversi

\footnotetext{
35 Sulistiowati, 2010, Aspek Hukum dan Realitas Bisnis Perusahaan Grup di Indonesia, Jakarta, Erlangga, hlm. 3.

36 Supra no 19, Pasal 21 ayat (1).
} 
tersebut tidak merugikan pemegang polis, sehingga pemegang polis mengetahui rencana konversi dan tata cara penyelesaian hak-haknya, termasuk dalam hal pemegang polis ada yang keberatan untuk dapat dilakukan pemindahan portofolio pertanggungan kepada Perusahaan Asuransi lain atau menerima pembayaran bagian premi dan/atau nilai tunai pertanggungan. ${ }^{37}$ Selain tidak boleh merugikan pemegang polis atau tertanggung, aktivitas pemisahan, akuisisi, dan konversi juga tidak boleh merugikan pemegang saham dan karyawan.

Dalam hal terjadi ketidaksetujuan terhadap rencana penyelesaian hak-hak kepesertaan sebagaimana tertuang dalam pengumuman yang merupakan salah satu kewajiban pelaku usaha yang bersifat preventif berupa penyampaian informasi yang terkini dan mudah diakses kepada Konsumen tentang produk dan/atau layanan ${ }^{38}$, maka pemegang polis sebagai konsumen sektor jasa keuangan berhak mengajukan pengaduan melalui Layanan Pengaduan dari perusahaan asuransi/reasuransi yang bersangkutan guna mendapatkan penyelesaian pengaduan dalam rangka perlindungan konsumen, sebagaimana diatur dalam POJK No. 18/POJK.07/2018 tentang Layanan Pengaduan Konsumen Sektor Jasa Keuangan. Ruang lingkup dari layanan pengaduan yang diatur dalam Pasal 3 POJK a quo terdiri dari penerimaan pengaduan, penanganan pengaduan, dan penyelesaian pengaduan. Dalam hal pemegang polis selaku konsumen menolak tanggapan pengaduan dari perusahaan, maka menurut Pasal 25 POJK $a$ quo, perusahaan diwajibkan memberikan informasi kepada pemegang polis/perwakilannya mengenai upaya penyelesaian sengketa yang dapat dilakukan melalui pengadilan atau di luar pengadilan.

Mendasarkan pada adanya pengumuman tersebut, pihak-pihak terkait memiliki kesempatan untuk merespon adanya rencana pemisahan (spin-off) Unit Syariah, baik yang didahului dengan pengambilalihan (akuisisi) dan konversi Perusahaan Asuransi/Reasurasi lain, maupun yang langsung dengan mendirikan badan hukum baru atau dengan kata lain adanya pengumuman atas rencana

\footnotetext{
Id., Pasal 15 POJK.

38 Peraturan Otoritas Jasa Keuangan, No. 1/POJK.07/2013 tentang Perlindungan Konsumen Sektor Jasa Keuangan, L.N.R.I Tahun 2014 No. 12, Pasal 5.
} 
pemisahan dilakukan guna memenuhi prinsip kesukarelaan (taradlin). Pada bagian terakhir ini, Penulis sampaikan mengenai perlakuan terhadap tiga pihak yang sangat terkait dengan aktivitas perusahaan dimaksud, yakni Peserta Program Asuransi (Pemegang Polis/Tertanggung), karyawan, dan pemegang saham.

\section{Peserta Program Asuransi (Pemegang Polis/Tertanggung)}

Peserta Program Asuransi atau yang dalam istilah hukum disebut Pemegang Polis/Tertanggung adalah pihak yang harus pertama kali diperhatikan manakala suatu Perusahaan hendak melakukan suatu aktivitas perusahaan berupa Pemisahan Unit Syariah, khususnya dalam Pemisahan yang menggunakan skema acquisition model. Dalam pure model pada prinsipnya tidak menimbulkan persoalan hukum yang berarti, karena pemegang polis/tertanggung tetap mendapatkan layanan yang sama paling tidak ditinjau dari penerapan Prinsip Syariah dalam program asuransi yang diikuti. Menjadi persoalan manakala dalam rangka Pemisahan Unit Syariah menggunakan acquisition model, yakni terhadap pemegang polis/tertanggung dari Perusahaan yang menjadi target akuisisi yang mana awalnya pemegang polis/tertanggung mengikuti program asuransi/reasuransi konvensional. Apabila ini terjadi, maka berdasarkan pada Pasal 15 POJK No. 67/POJK.05/2016, menurut Penulis melahirkan tiga alternatif yang dapat ditawarkan kepada pemegang polis, yakni bagi pemegang polis yang bersedia bertahan di Perusahaan Asuransi/Reasuransi Syariah yang merupakan hasil konversi dalam rangka Pemisahan Unit Syariah dilakukan konversi akad, sedangkan bagi yang tidak bersedia mengikuti program asuransi syariah dapat dialihkan kepada induk dari Perusahaan Asuransi/Reasuransi Syariah tersebut yang memang dikelola secara konvensional atau dilakukan pembayaran bagian premi dan/atau nilai tunai pertanggungan. Alternatif kedua dan ketiga berupa pengalihan kepada Perusahaan Asuransi/Reasuransi sebagai induk perusahaan atau pembayaran premi terbayar dan/atau nilai tunai pertanggungan kepada pemegang polis/tertanggung adalah hal yang relatif mudah, sepanjang Perusahaan Asuransi/Reasuransi yang melakukan akuisisi dan konversi dalam 
rangka Pemisahan Unit Syariah memiliki kesediaan untuk menerima portofolio kepesertaan dan ketersediaan dana yang cukup. Sementara alternatif pertama bagi pemegang polis yang bersedia dikonversi sebagai program asuransi syariah sehingga perlu dilakukan konversi akad justru tidak mudah, karena hingga saat ini belum ada regulasi maupun fatwa Dewan Syariah Nasional - Majelis Ulama Indonesia (DSN-MUI) yang memberikan panduan/pengaturan khusus mengenai tata cara konversi akad dalam perasuransian.

Apabila alternatif kedua digantungkan kepada kesediaan untuk menerima portofolio kepesertaan, yakni dapat melalui lembaga cessie ${ }^{39}$ dan alternatif ketiga digantungkan pada ketersediaan dana yang cukup dari perusahaan untuk pembayaran premi terbayar dan/atau nilai tunai pertanggungan, maka terhadap alternatif pertama yang perlu dipikirkan adalah mekanisme konversi akad. Dengan tidak adanya fatwa dan regulasi khusus mengenai konversi akad, maka menurut Penulis yang perlu dilakukan adalah dengan melakukan konstruksi hukum mendasarkan pada regulasi umum yang mengatur penyelenggaraan usaha asuransi.

Guna mendapatkan solusi terhadap persoalan melalui konstruksi hukum, maka terlebih dahulu perlu diketahui term prinsip syariah, akad, dan klasifikasi akad yang dikenal dalam asuransi syariah. Dalam Pasal 1 angka 19 POJK No. 69/POJK.05/2016 tentang Penyelenggaraan Usaha Asuransi, Perusahaan Asuransi Syariah, Perusahaan Reasuransi, dan Perusahaan Reasuransi Syariah, Prinsip Syariah didefinisikan sebagai prinsip hukum Islam dalam kegiatan perasuransian berdasarkan fatwa yang dikeluarkan oleh lembaga yang memiliki kewenangan dalam penetapan fatwa di bidang syariah, sedangkan definsi Akad tertuang dalam Pasal 1 angka 30 POJK a quo, yakni perjanjian tertulis yang memuat kesepakatan tertentu, beserta hak dan kewajiban para pihak sesuai Prinsip Syariah.

Kemudian, apabila ditinjau dari akad-akad yang ada di asuransi secara garis besar dapat diklasifikasikan ke dalam dua jenis akad, yakni Akad Tabarru'

39 Cessie adalah suatu pengalihan piutang atas nama yang diatur dalam Pasal 613 KUHPerdata. Dalam hal ini perusahaan induk sebagai penerima pengalihan akan memiliki hak tagih terhadap sisa pembayaran premi dari pemegang polis. 
dan Akad Tijarah. Akad Tabarru' adalah akad hibah dalam bentuk pemberian dana dari satu peserta kepada Dana Tabarru' untuk tujuan tolong menolong di antara para peserta, yang tidak bersifat dan bukan untuk tujuan komersial, sedangkan Akad Tijarah adalah akad antara peserta secara kolektif atau secara individu dan Perusahaan dengan tujuan komersial. ${ }^{40}$ Keberadaan akad tabarru' yang merupakan realiasi dari prinsip tolong-menolong (ta'awun) ini tidak dijumpai dalam asuransi konvensional, karena dalam asuransi konvensional perusahaan bertanggungjawab penuh mengganti kerugian tertanggung sebagai kontraprestasi atas premi yang diterima secara paralel dengan kontrak penjualan. ${ }^{41}$

Berdasarkan definisi Prinsip Syariah, Akad, dan klasifikasi akad tersebut dapat Penulis tegaskan bahwa berbeda dengan asuransi konvensional yang hanya mengenal hubungan hukum antara pemegang polis dan perusahaan asuransi/reasuransi sebagai konsekuensi dari adanya prinsip risk transferring, sedangkan dalam asuransi/reasuransi syariah dikenal hubungan hukum antar peserta asuransi dan antara peserta dengan perusahaan asuransi/reasuransi sebagai konskuensi dari adanya prinsip risk sharing. Hal mana dalam POJK No. 69/POJK.05/2016, ditegaskan bahwa keberadaan Akad Tabarru' dan Akad Tijarah dalam aktivitas Perusahaan Asuransi/Reasuransi Syariah adalah wajib, serta dituangkan ke dalam Polis asuransi syariah atau perjanjian reasuransi syariah. ${ }^{42}$

Dengan tetap menyetujui menjadi pemegang polis/tertanggung pada Perusahaan Asuransi/Reasuransi Syariah hasil akuisisi dan konversi dalam rangka pemisahan, maka perjanjian asuransi/polis dari peserta yang bersangkutan perlu dikonversi ke dalam Akad Tabarru' dan Akad Tijarah. Premi yang sudah dibayarkan dalam periode tertentu menurut Penulis tetap diberlakukan sebagai dana tijarah (komersil) sehingga pemegang polis berhak atas manfaat asuransi berdasarkan akad tijarah yang digunakan, sedangkan sejak tanggal efektif Perusahaan Asuransi/Reasuransi Syariah hasil akuisisi dan

\footnotetext{
40 Supra, No 19, Pasal 1 angka 31 dan 32.

41 Kamaruzaman Noordin, et.al. The Commercialization of Modern Islamic Insurance Providers: A Study of Takaful Business Frameworks in Malaysia, International Journal of Nusantara Islam, Vol, 2 No, 12014 , hlm. 11.

42 Supra, No 19, Pasal 54 ayat (1).
} 
konversi dalam rangka Pemisahan melaksanakan kegiatan usaha sesuai dengan Prinsip Syariah, maka perlu ada negosiasi antara perusahaan dan pemegang polis untuk menyepakati porsi dana guna dimasukkan ke akun tabarru' dan akun tijarah. Hal ini menjadi penting, karena keberadaan dana tabarru' dalam asuransi/reasuransi syariah adalah dalam rangka pelaksanaan prinsip tolongmenolong antar peserta (ta'awun dan risk sharing) dalam bentuk saling bertanggung jawab (mutual responsibility), kerjasama (cooperation), dan saling melindungi (mutual protection). ${ }^{43}$

Akad Tijarah yang dapat diterapkan ke dalam konversi akad berdasarkan pada POJK a quo terdiri dari:

1. Wakalah bil Ujrah, yakni Akad Tijarah yang memberikan kuasa kepada Perusahaan Asuransi Syariah/Reasuransi Syariah/Unit Syariah sebagai wakil peserta untuk mengelola Dana Tabarru' dan/atau Dana Investasi Peserta dengan imbalan berupa ujrah (fee).

2. Mudharabah, yakni Akad Tijarah yang memberikan kuasa kepada Perusahaan Asuransi Syariah/Reasuransi Syariah/Unit Syariah sebagai mudharib (pengelola dana) untuk mengelola Dana Tabarru' dan/atau Dana Investasi Peserta dengan imbalan berupa bagi hasil yang besarnya telah disepakati sebelumnya.

3. Mudharabah Musytarakah, yakni Akad Tijarah yang memberikan kuasa kepada Perusahaan Asuransi Syariah/Reasuransi Syariah/Unit Syariah sebagai mudharib (pengelola dana) untuk mengelola investasi Dana Tabarru' dan/atau Dana Investasi Peserta, yang digabungkan dengan kekayaan Perusahaan Asuransi Syariah/Reasuransi Syariah/Unit Syariah dengan imbalan berupa bagi hasil (nisbah) yang besarnya ditentukan berdasarkan komposisi kekayaan yang digabungkan dan telah disepakati sebelumnya. ${ }^{44}$

Dari tiga macam akad tijarah tersebut, para pihak (Perusahaan Asuransi/Reasuransi Syariah dan pemegang polis) dapat memilih salah satu dan

43 Sudin Haron and Wan Nursofiza Wan Azmi, 2009, Islamic Finance and Banking System (Philosophies, Principles \& Practices), McGraw-Hill Education, Malaysia, Sdn Bhd, hlm. 437.

44 Supra, No 19, Ketentuan Umum Pasal 1 angka 33, 34, dan 35 P0JK. 
apabila sudah memilih, maka wajib dilakukan secara konsisten sampai berakhirnya polis asuransi syariah. Dalam hal disepakati perubahan Akad Tijarah, penggunaan Akad Tijarah yang baru hanya dapat diterapkan pada polis asuransi syariah yang baru. Apapun Akad Tijarah yang dipilih, Perusahaan Asuransi/Reasuransi Syariah wajib menangung seluruh kerugian yang terjadi dalam kegiatan pengelolaan risiko dan/atau kegiatan pengelolaan investasi yang diakibatkan oleh kesalahan yang disengaja, kelalaian, atau wanprestasi yang dilakukan Perusahaan Asuransi/Reasuransi Syariah. ${ }^{45}$ Penggunaan akad selain dari ketiga akad tersebut hanya dapat dilakukan sepanjang berdasarkan fatwa DSN-MUI dan terlebih dahulu memperoleh persetujuan dari OJK.46 Malaysia sebagai negara yang memiliki kerangka hukum dan kelembagaan yang maju di bidang takaful, selain menggunakan model mudharabah dan wakalah, juga dimungkinkan menggunakan hybrid model (mudarabah-wakalah model), waqf model, dan wadi'ah model.47 Artinya dalam rangka konversi akad, Perusahaan Asuransi/Reasuransi Syariah juga dapat mencontoh Malaysia dengan terlebih dahulu mengajukan izin ke OJK, karena selain waqf model, penggunaan akad wadiah, mudharabah, dan wakalah sudah mendapatkan fatwa DSN-MUI, yakni: (1) Fatwa DSN-MUI No. 21/DSN-MUI/X/2001 tentang Pedoman Umum Asuransi Syariah; (2) Fatwa DSN-MUI No. 52/DSN-MUI/III/2006 tentang Akad Wakalah Bil Ujrah Pada Asuransi dan Reasuransi Syariah; dan (3) Fatwa DSN-MUI No. 53/DSNMUI/III/2006 tentang Akad Tabarru' Pada Asuransi dan Reasuransi Syariah.

Premi yang sudah terbayar pada saat pemegang polis masih berada dalam perusahaan asuransi/reasuransi konvensional dianggap sebagai dana investasi, sedangkan pasca bertransformasi menjadi Perusahaan Asuransi/Reasuransi Syariah premi yang dibayar harus ada sebagian yang dimasukkan ke dalam dana tabarru' dan sebagian yang lain dimasukkan ke dalam dana investasi, yang mana porsi untuk kedua jenis dana tersebut harus didasarkan pada kesepakatan

\footnotetext{
Id., Pasal 54 ayat (3), (4), (5) dan (8).

Id., Pasal 55 ayat (1) ayat (2).

47 Lihat Zaharuddin Abd.Rahman, 2014, Contemporary Islamic Finance Architecture, IBFIM, Kuala Lumpur, Malaysia, hlm. 293-295. Lihat pula Nafis Alam, 2017, Islamic Finance: A Practical Perspective, Palgrave Macmillan, Cham, Switzerland, hlm. 438-440.
} 
dan/atau ketentuan yang ada dalam program asuransi/reasuransi syariah yang diberikan.

Dengan demikian perlakuan yang dapat diberikan bagi para pemegang polis/tertanggung selaku peserta program asuransi atas terjadinya Pemisahan Unit Syariah, khususnya yang dilakukan dalam bentuk acquisition model yakni dengan menawarkan kepada seluruh pemegang polis untuk tetap bertahan di Perusahaan Asuransi/Reasuransi Syariah hasil Pemisahan Unit Syariah dengan dilakukan konversi akad, sedangkan bagi yang tidak bersedia bisa dialihkan kepada induk dari Perusahaan Asuransi/Reasuransi Syariah tersebut yang memang dikelola secara konvensional atau dilakukan pembayaran bagian premi dan/atau nilai tunai pertanggungan yang sudah berlangsung.

\section{Karyawan}

Bagi karyawan Unit Syariah dengan dilakukan Pemisahan dan bertransformasi ke dalam Perusahaan Asuransi/Reasuransi Syariah, khusus pure model bisa tetap bekerja di perusahaan yang merupakan badan hukum baru tersebut dengan atau tanpa pembaharuan perjanjian kerja. Sementara karyawan dari Perusahaan Asuransi/Reasuransi yang menjadi target akuisisi dan konversi dalam rangka pemisahan (acquisition model) dapat ditawarkan apakah tetap bergabung dengan perusahaan baru yang berbasis syariah tersebut atau kalau tidak bersedia dapat diberikan opsi untuk mengundurkan diri dengan dipenuhi hak-haknya sesuai dengan peraturan perundang-undangan di bidang ketenagakerjaan dan perjanjian kerja yang sudah ada sebelumnya. Dalam hal tetap bersedia bekerja di Perusahaan Asuransi/Reasuransi Syariah, maka terhadapnya perlu diberikan pendidikan dan pelatihan tentang perasuransian syariah.

Kebutuhan SDM akan meningkat seiring dengan pertumbuhan industri dan terlebih dengan adanya kewajiban spin-off Unit Syariah, khususnya untuk asuransi syariah. Sebagai perusahaan yang berdiri sendiri, perusahaan hasil spin-off tidak dapat menggunakan SDM dari bisnis konvensional yang selama ini menopang 
kinerja unit syariah. ${ }^{48}$ Dengan adanya peningkatan SDM ini menurut Penulis tetap bisa mempertahankan SDM yang ada di konvensional yang sudah tidak terikat lagi dengan perusahaan asuransi/reasuransi sebelumnya pasca akuisisi dan konversi, sehingga setelah mengikuti diklat tentang perasuransian syariah terhadapnya tetap bisa menjadi karyawan dari perusahaan asuransi/reasuransi syariah tersebut.

\section{Pemegang Saham}

Pemegang saham adalah pihak yang harus mendapatkan perlindungan pada saat akan dilakukan Pemisahan Unit Syariah. Secara preventif UndangUndang Nomor 40 Tahun 2007 tentang Perseroan Terbatas (UUPT) telah memberikan rambu-rambu kaitannya dengan adanya aktivitas perusahaan, termasuk Pemisahan (Spin-Off). Bahwa ketika perusahaan hendak melakukan aktivitas perusahaan berupa kegiatan pengambilalihan dan/atau pemisahan (spinoff), maka berdasarkan ketentuan Pasal 126 ayat (1) UUPT ada beberapa kepentingan yang harus diperhatikan salah satunya yakni pemegang saham minoritas. Perlakuan bagi pemegang saham yang relevan dalam konteks ini manakala tidak menyetujui ada aktivitas perusahaan dimaksud, yakni bahwa setiap pemegang saham berhak meminta kepada Perseroan agar sahamnya dibeli dengan harga yang wajar. ${ }^{49} \mathrm{Hal}$ ini meniscayakan bagi Perusahaan yang hendak malaksanakan Pemisahan Unit Syariah baik dengan pure model atau acquisition model untuk menyediakan dana yang cukup untuk membeli saham sesuai dengan harga yang wajar bagi pemegang saham yang tidak menyetujui adanya Pemisahan.

Dengan demikian, Perlakuan terhadap ketiga pihak sebagaimana tersebut di atas dilakukan dalam rangka purifikasi terhadap aset dan liabilitas dari Perusahaan Asuransi/Reasuransi sebelum bertransformasi ke dalam Perusahaan Asuransi/Reasuransi Syariah dengan skema Pemisahan, baik dengan pure model,

48 Otoritas Jasa Keuangan, Roadmap IKNB Syariah 2015-2019, Otoritas Jasa Keuangan, Jakarta, hlm. 39.

49 Undang-Undang R.I., No. 40 Tahun 2007, Perseroan Terbatas L.N.R.I Tahun 2007 No. 106, Pasal 62 ayat (1). 
maupun acquisition model. Purifikasi menjadi penting guna memastikan proses Pemisahan Unit Syariah sejalan dengan Prinsip Syariah, yakni dalam rangka meminimalisir keberadaan unsur-unsur yang dilarang dan memaksimalkan dipenuhinya prinsip-prinsip dasar dalam penyelenggaraan kegiatan usaha Perusahaan Asuransi/Reasuransi Syariah.

\section{Penutup}

Pemisahan Unit Syariah memiliki urgensi guna memisahkan tata kelola syariah dari Perusahaan Asuransi/Reasuransi konvensional. Alternatif cara Pemisahan Unit Syariah yang diberikan oleh regulasi memiliki keunggulan dan kelemahan masing-masing. Cara pertama, yang Penulis sebut sebagai pure model tidak mengalami kompleksitas berkaitan dengan isu sharia compliance, sedangkan cara kedua yang Penulis sebut dengan acquisition model memiliki keunggulan dari aspek perizinan, yakni cukup mengajukan izin konversi. Sebaliknya, cara pertama memiliki kelemahan, yakni memerlukan dua macam izin berupa izin prinsip dan izin usaha, serta memerlukan permodalan yang kuat, sedangkan cara kedua memiliki kelemahan berupa kompleksitas konversi perjanjian perasuransian ke dalam akad syariah.

Status aset Unit Syariah sebelum Pemisahan adalah menjadi milik Perusahaan Asuransi/Reasuransi Konvensional, sedangkan setelah Pemisahan menjadi milik Perusahaan Asuransi/Reasuransi Syariah hasil pemisahan. Khusus dalam acquisition model perlu diperhatikan terkait dengan perlakuan terhadap aset dan liabilitas dalam rangka purifikasi, guna memastikan proses Pemisahan Unit Syariah sejalan dengan Prinsip Syariah. Purifikasi dilakukan dengan memberikan tawaran kepada peserta/pemegang polis untuk tetap berada di Perusahaan Asuransi/Reasuransi Syariah hasil konversi dengan dilakukan konversi kepesertaan dari berbasis konvensional ke basis syariah dengan menggunakan akad-akad tertentu atau diselesaikan hak dan kewajibannya sesuai polis bagi peserta asuransi yang tidak bersedia dilakukan konversi kepesertaan tersebut. 


\section{Daftar Pustaka}

Buku:

Adiwarman A. Karim dan Oni Sahroni, Riba, Gharar, dan Kaidah-Kaidah Ekonomi Syariah : Analisis Fikih dan Ekonomi, Raja Grafindo Persada, Jakarta, 2015.

Nafis Alam, Islamic Finance: A Practical Perspective, Palgrave Macmillan, Cham, Switzerland, 2017.

Peter Mahmud Marzuki, Penelitian Hukum, Edisi Revisi, Kencana, Jakarta, 2005.

Sudin Haron and Wan Nursofiza Wan Azmi, Islamic Finance and Banking System (Philosophies, Principles \& Practices), McGraw-Hill Education, Malaysia, 2009.

Sulistiowati, Aspek dan Realitas Bisnis Perusahaan Grup di Indonesia, Erlangga, Jakarta, 2010.

Tim Laskar Pelangi, 2013, Metodologi Fiqih Muamalah: Diskursus Metodologis Konsep Interaksi Sosial-Ekonomi, Lirboyo Press, Kediri.

Zaharuddin Abd. Rahman, Contemporary Islamic Finance Architecture, IBFIM, Kuala Lumpur, Malaysia, 2014.

\section{Jurnal:}

Kamaruzaman Noordin, et.al. The Commercialization of Modern Islamic Insurance Providers: A Study of Takaful Business Frameworks in Malaysia, International Journal of Nusantara Islam, Vol, 2 No, 1, 2014.

Lita Wulandari, et. al. Spin Off Feasibility Study of Sharia Financing Unit: Study in Adira Finance, 10, Jurnal Al-Iqtishad, Vol. 10, No. 2, July 2018.

Lokot Zein Nasution, Strategi Spin-Off Bagi Pengembangan Keuangan Syariah: Tinjauan Pada Kasus Asuransi Syariah, Jurnal Dinamika Ekonomi Pembangunan (JDEP), Vol. 2, No. 2, 2019.

M. Nur Rianto Al Arif, The Effect of Spin-Off Policy on Financing Growth in Indonesian Islamic Banking Industry, Jurnal Al-Ulum Vol. 15, No. 1, June 2015.

Nikmah Mentari dan Franciska Mifanyira Sutikno, Sustainable Development Goals (SDGs) Principle Towards Sharia Business Unit Pres-Spin Off 2023, Jurnal UNIFIKASI, Vol. 06, No. 02, 2019.

Nursania Dasopang, Tinjauan Hukum Pemisahan (Spin-Off) Unit Usaha Syariah Menjadi Perusahaan Asuransi Syariah (Full Fledge), Jurnal Yurisprudentia, Vol. 5, No. 1, Juni 2019.

Rachma Indraini, et. al, Efficiency Determinants of Islamic Insurance in Indonesia, Conference Paper dalam $2^{\text {nd }}$ ICIEBP Volume 2019.

Sunarsih dan Fitriyani, Analisis Efisiensi Asuransi Syariah di Indonesia tahun 2014-2016 dengan Metode Data Envelopment Analysis (DEA), Jurnal Ekonomi \& Keuangan Islam, Vol. 4, No. 1, Januari 2018.

Wardah Yuspin dan Kelik Wardiano, Islamic Banking Trajectories of Indonesia: Dealing with the Present and Shaping the Future, International Journal of Economic Research, Vol 14, No. 16 (Part 2), 2017. 


\section{Referensi Yang Dipublikasi:}

Disertasi, Khotibul Umam, Transformasi Kelembagaan Unit Usaha Syariah ke dalam Bank Umum Syariah di Indonesia, Doktor Ilmu Hukum UGM.

Lokot Zein Nasution, Strategi Spin-Off Bagi Pengembangan Keuangan Syariah: Tinjauan Pada Kasus Asuransi Syariah, Jurnal Dinamika Ekonomi Pembangunan (JDEP), Vol. 2 No.2, 225, 2019.

\section{Web Dokumen:}

Askrida, https://drive.google.com/file/d/1zKnhqPdM71bswybt6UjHrlwTpUSOagG/view, diakses 25 Desember, 2020

Askrida Syariah, http://askridasyariah.co.id/berita/grand-launching-askridasyariah, diakses 5 Juni, 2020.

Askrida Syariah, http://www.askrindosyariah.co.id/foto_berita/47Annual_Report_Askrindo _Syariah-2018.pdf, diakses 25 Desember, 2020, hlm. 6-7

CNN Indonesia, OJK: Baru 4 Unit Syariah yang "Pisah" dari Induk Asuransi: https://www.cnnindonesia.com/ekonomi/20190517160559-78395823/ojk-baru-4-unit-syariah-yang-pisah-dari-induk-asuransi, diakses 10 Mei, 2020.

Eduardo Simorangkir, Resmi Merger BUMN Reasuransi Ini Siap Go Internasional: https://finance.detik.com/bursa-dan-valas/d-3240765/resmi-mergerbumn-reasuransi-ini-siap-go-internasional, diakses 15 Juni, 2020.

Kelvin Hianusa, Standard an Alternatif Pemisahan Unit Usaha Syariah Disiapkan: https://kompas.id/baca/utama/2019/09/27/standar-dan-alternatifpemisahan-unit-usaha-syariah-disiapkan/, diakses 18 Maret, 2020.

Lifepal: https://lifepal.co.id/asuransi/jasindo-syariah/, diakses 14 Juni, 2020. Otoritas Jasa Keuangan, FAQ POJK No. 67/POJK.05/2016 tentang Perizinan Usaha dan Kelembagaan Perusahaan Asuransi, Perusahaan Asuransi Syariah, Perusahaan Reasuransi, dan Perusahaan Reasuransi Syariah:https://www.ojk.go.id/id/kanal/iknb/regulasi/asuransi/peratura nojk/Documents/Pages/POJK-tentang-Perizinan-Usaha-dan-KelembagaanPerusahaan-Asuransi,-Perusahaan-Asuransi-Syariah,-PerusahaanReasuransi/FAQ\%20POJK\%2067-2016.pdf, diakses 4 September, 2020.

Republika, OJK Sebut 10 UUS Asuransi Berencana Spin Off: https://republika.co.id/berita/q0qk3m370/ojk-sebut-10-uus-asuransiberencana-emspin-offem, diakses 18 Maret, 2020.

\section{Peraturan Perundang-undangan:}

Undang Undang R.I., No. 40 Tahun 2014, Perasuransian, L.N.R.I Tahun 2014 No. 337.

Undang-Undang R.I., No. 40 Tahun 2007, Perseroan Terbatas L.N.R.I Tahun 2007 No. 106.

Peraturan Otoritas Jasa Keuangan, No. 1/POJK.07/2013 tentang Perlindungan Konsumen Sektor Jasa Keuangan, L.N.R.I Tahun 2014 No. 12.

Peraturan Otoritas Jasa Keuangan, No. 67/POJK.05/2016, Perizinan Usaha dan Kelembagaan Perusahaan Asuransi, Perusahaan Asuransi Syariah, 
Perusahaan Reasuransi, dan Perusahaan Reasuransi Syariah, L..N.R.I Tahun 2016 No. 33.

Peraturan Otoritas Jasa Keuangan, No. 69/POJK.05/2016, Penyelenggaraan Usaha Asuransi, Perusahaan Asuransi Syariah, Perusahaan Reasuransi, dan Perusahaan Reasuransi Syariah, L.N.R.I Tahun 2016 No. 302.

Peraturan Otoritas Jasa Keuangan, No. 18/POJK.07/2018 tentang Layanan Pengaduan Konsumen Sektor Jasa Keuangan, L.N.R.I Tahun 2018 No. 141. 